\title{
IAMJ
}

INTERNATIONAL

AYURVEDIC

MEDICAL JOURNAL

ISSN: 2320-5091

Impact Factor: 6.719

\section{THE PHYSIOLOGICAL STUDY OF SANCHAYAVSTHA OF SATHKRIYAKALA W.S.R SEASONS (RITUS)}

\author{
Mukesh Saini' ${ }^{1}$ Rajesh Kumar Sharma ${ }^{2}$, Dinesh Chandra Sharma ${ }^{3}$ \\ ${ }^{1}$ P.G. Scholar, P.G. Department of Kriya Sharir, Dsrrau, Jodhpur, Rajasthan, India \\ ${ }^{2}$ Associate Professor and H.O.D., P.G. Department of Kriya Sharir, Dsrrau, Jodhpur, Rajasthan, India \\ ${ }^{3}$ Assistant Professor, P.G. Department of Kriya Sharir, Dsrrau, Jodhpur, Rajasthan, India
}

Corresponding Author: arjunsaini325@gmail.com

https://doi.org/10.46607/iamj.2709012021

(Published online: January 2021)

Open Access

(C) International Ayurvedic Medical Journal, India 2021

Article Received: 17/12/2020 - Peer Reviewed: 22/12/2020 - Accepted for Publication: 25/12/2020

Check for updates

\section{ABSTRACT}

The Prayojana of Ayurveda is of two types, Maintenance of health a healthy Person, by adopting the Ritucharya, Dincharya and Sadvritta and curing of a disease of diseased Person, by adopting therapeutic measures. Kriya means Action or treatment. Kala means Time or period. So Shatkriyakala means 'Appropriate time Periods to take action/treatment. Acharya Susrutha has narrated detail idea of Shatkriyakala in 21st chapter of Sutrasthana. Shatkriyakala include six stages viz Sanchaya, Prakopa, Prasara, Sthansamshraya, Vyaktavastha and Bhedavastha. That means 6 (the number Six). Shatkriyakala is distinctive concept of Ayurveda. By knowing the process of shatkriyakala the disease process can be arrest at initial stage and avoid the Probabilities of complications. Acharya Sushrutha already mentions the Kriyakala helps the physician to adopt line of treatment by seeing the vitiated Dosha condition by his intellect and knowledge. So, we can say that the physician who diagnose a disease and treat according to Shatkriyakala will be become a successful Practitioner.

Keywords: Ayurveda, Shatkriyakala, Ritucharya, Dincharya 


\section{INTRODUCTION}

The term Kriya kala refers to the recognition of the stage of a disease's Progress. This concept is mostly compared with disease Pathogenesis. Kriya kala means the time of treatment or interception in the process of disease manifestation. Kriya means Action or treatment. Kala means Time or period. Before Studying the Pathological conditions of the body, a Physician has to first study the occult function and structures of the body on the basic of dosa, dushya and Srotas. At that time kriya Kala helps the doctor to adopt line of treatment by seeing the vitiated dosha condition by his intellect and knowledge. The Prime factors in the Pathogenesis of a disease are Dosha and Dushyas (Body elements). If a Person not undergone for the treatment, the vitiated Doshas are further developed and evaluated Phases of the Process of disease takes Place. According to Ayurveda vitiated dosha affects the other body elements of these results in the formation of disease. So, the complete knowledge of Shatkriyakala is very essential to cure the disease. The Vyadhi Kriya Kala is explained by Susrutha having six stages, consider as shatkriyakala. In modern Science, disease can be recognized in two stages, the first stage is detections of the disease, and the second encompasses the complication due to Particular disease. However, Ayurveda identifies six stages of any disease (Shatkriyakala). Interestingly, before the appearance of external symptoms, Ayurveda has the ability to detect and treat the underlying cause of a disease. The main active factors in the development of a disease are Ama (autotoxin) Toxicity and the mobility of the Doshas (biological factors). Ayurveda consider all diseases result from gross, systemic Imbalances and malfunctions of three doshas vata, Pitta and Kapha. Mainly Kriya Kala is divided into two types is Ritu Kriya Kala and Vyadhi Kriya kala.

Table 1:

\begin{tabular}{|l|l|}
\hline Ritu Kriya Kala & Vyadhi Kriya kala \\
\hline 1. Chaya & 1. Sthansamshraya-avastha \\
\hline 2. kopa & 2. Vyakt-avastha \\
\hline 3. Prashama. & 3. Bhed-avastha \\
\hline
\end{tabular}

Table 2: Material and Methods: According to Acharya Shushurut Shatkriyakala include six stages

\begin{tabular}{|l|l|}
\hline 1. Sanchay- avastha & 1. Stage of Accumulation \\
\hline 2. Prakop-avastha & 2. Stage of Aggravation \\
\hline 3. Prasar-avastha & 3. Stage of Spread \\
\hline 4. Sthansamshraya-avastha & 4. Stage of Localization \\
\hline 5. Vyakt-avastha & 5. Stage of Manifestation \\
\hline 6. Bhed-avastha & 6. Stage of Differentiation \\
\hline
\end{tabular}

\section{Sanchay-avastha}

Increase of Doshas in their own sites is called as Sanchya and Produces dislike for things which causes of increase and liking for the things of opposite qualities. In this stage mild symptoms are seen. This it is very beneficial to cure the Person is this stage. These deranged Doshas are rendered in this stage they are not able to move into next stage. If they are neglected and not treated, they became stronger and more intensive in the course of their next developments. In
Sanchaya Patient Want Opposite guna (quality) of Rasa (Taste) for example, an intake of sweets when kapha gets sanchayavastha the Person will have aversion to sweets and want to consume opposite guna (quality) of Rasa (Taste). That is a Proper indication of Sanchayavastha of Particular doshas, and this is a Proper time to assess the accumulated doshas and take Proper line of treatment, If Persons adopted the regimen of existing ritu these doshas will bring back to the normal stage. Relation of dosha and ritu are- 
Table 3:

\begin{tabular}{|l|l|l|l|}
\hline Dosha & Chaya & Prakopa & Prashama \\
\hline Vata & Grishma (summer) & Varsha (monsoon) & Sharada (autumn) \\
\hline Pitta & Varsha (monsoon) & Sharada (autumn) & Hemanta (fall winter) \\
\hline Kapha & Shishira (winter) & Vasanta (spring) & Grishma (summer) \\
\hline
\end{tabular}

Etiology: The etiology of Sanchya can be classified into-

1. Kala swabhava (natural)

2. Trividha Hetu (Three types of causative factors)

Trividha Hetu can be classified into-

\section{Pragynaparadha (misleads)}

2. Asatmendriyarthe Samyoga (improper uses of Sensory organs)

3. vyapanna hetu (inherent cause).

Table 4: Symptoms

\begin{tabular}{|l|l|l|}
\hline Dosha & Clinical Features (Ayurveda) & Clinical Features (Modern) \\
\hline Vata & Stabdha purna Koshtata & Feeling of obstruction \& Fullness in the organ \\
\hline Pitta & Pitava bhasata & Yellow coloration \\
\hline Kapha & 1. Manda Ushmata & Low body temperature or Low Digestive Fire \\
\hline & 2. Anganam Gauravam & Heaviness of organ like Legs or Heaviness of Body \\
\hline & 3. Alasya & Lethargy or Laziness \\
\hline
\end{tabular}

\section{DISCUSSION}

Ayurveda is a science of life. The principal object of Ayurveda is not only to cure the disease, but also to prevent the individuals from all sorts of miseries of life, which one has to face in day-to-day busy life. Early diagnosis of disease helps to cure the diseases successfully without much discomfort. Ayurveda suggest following the daily and seasonal regimen as Preventive measure. The Tridoshas are always having a vitiation tendency. This Property is due to the change in both the internal and external environment of the living beings. The internal environmental changes are due to the irregularities in daily and seasonal lifestyle, which are not helping to health and causes vitiation of doshas or Dosha Prakopa.

\section{CONCLUSION}

Ritus (season cycle) have different characters, responsible for increase in same qualities in nature, as well as in human being and depresses the opposite qualities also. This is the reason for the Chaya, Prakopa and Prashama of Tridoshas in the human beings in corresponding Ritus (season). This variation of Tridoshas is not of the same quality in every individual. Nowadays, the nature is changing its qualities due to various atmospheric changes like pollution, space experiments, heavy industrialization and population crisis. So, while studying the effects of Ritu (season) one has to face the hyper/ hypo and perverted faculties of Ritu (season) which are affecting the generations. So, the study of Ritu (season) in respect of its various effects will be the essential thing in future. In other Ritus, Ritucharya (seasonal lifestyle) should be followed according to Dosha state. Panchakarma should be done to cleans the body due to different stages of Doshas e.g. Chaya, Prakopa, Prasara. Thus, Kala (season) is a major contributory factor in the various changes in the nature as well as in human body also.

\section{REFERENCE}

1. Chaturvedi G, Pandey K, editor, (1 ${ }^{\text {st }}$ Ed.) Charak Samhita of Agnivesha Vol-1, Sutrasthanam, Tasyashiteeya Adhyaya, Chapter 6, verse 10,20,22,27,34 and 41. Varanasi Chaukhambha Vishvabharti Prakashana, Reprint 2017.

2. Shastri AD, editor, (1 $1^{\text {st }}$ Ed.) Vol-1, Sushruta Samhita of Sushruta, Sutrasthanam, Rithucharyaadhyaya, Chapter 6, verse 14, 15, 16, and 40, reprint 2017.

3. Shastri AD, editor, ( $1^{\text {st }}$ Ed.) Vol-1, Sushruta Samhita of Sushruta, Sutrasthanam, Vranaprasnamadhyaya, Chapter 21, verse 18, 36, and 37, reprint 2017. 
4. Pro. Ravidutt Tripathi, editor, ( $1^{\text {st }}$ Ed.) Vol-1, Ashtangahridayam of Srimadvagbhata, Sutrasthanam, Rithucharyaadhyaya, Chapter 3, verse 46, 55 and 56, reprint 2012.

5. Pro. Ravidutt Tripathi, editor, $\left(1^{\text {st }}\right.$ Ed.) Vol-1, Ashtangahridayam of Srimadvagbhata, Sutrasthanam, Doshabhediyaadhyaya, Chapter 12, verse 19, 20, 21, 24, 25 and 28, reprint 2012.

\section{Source of Support: Nil \\ Conflict of Interest: None Declared}

How to cite this URL: Mukesh Saini: The Physiological Study of Sanchayavstha Of Sathkriyakala w.s.r Seasons (Ritus). International Ayurvedic Medical Journal \{online\} 2021 \{cited January, 2021\} Available from: http://www.iamj.in/posts/images/upload/171_174.pdf 